\title{
Analiza możliwości podwyższenia stabilności termicznej płuczek wiertniczych poprzez dobór środków chemicznych
}

\author{
Possibility of increasing the thermal stability of drilling muds through the use of \\ chemicals agents
}

\author{
Bartłomiej Jasiński \\ Instytut Nafty i Gazu - Państwowy Instytut Badawczy
}

\begin{abstract}
STRESZCZENIE: Wiercenie otworów o znacznej głębokości lub w celu udostępniania wód termalnych stawia coraz wyższe wymagania wobec właściwości stosowanych płuczek wiertniczych. Z uwagi na bardzo wysoką temperaturę utrzymywanie w czasie wiercenia odpowiedniej reologii płuczki może okazać się trudne, szczególnie w przypadku występowania dopływu wysokozmineralizowych solanek. Odziaływanie wysokiej temperatury powoduje znaczne obniżenie efektywności działania większości stosowanych obecnie w technologii płuczkowej środków polimerowych, w skrajnych przypadkach powodując całkowite i nieodwracalne zniszczenie ich struktury. Najbardziej narażone są polimery o wiązaniach eterowych, do których zalicza się środki skrobiowe i celulozowe. Na podstawie danych literaturowych można stwierdzić, że niekorzystne cechy tych polimerów mogą być skutecznie kompensowane dodatkami polimerów syntetycznych, np. sulfonowanych. Kolejnym kierunkiem w polepszaniu odporności termicznej płuczek wskazywanym przez literaturę jest wykorzystanie nanocząsteczek węgla: płatków grafenu i nanorurek. W artykule przedstawiono analizę możliwości poprawy stabilności termicznej płuczek wiertniczych poprzez zastosowanie środków chemicznych pozwalających zachować odpowiednie parametry reologiczno-strukturalne i filtrację w zakresie temperatury do $130^{\circ} \mathrm{C} . \mathrm{W}$ toku badań do płuczki polimerowo-potasowej dodawano trzy rodzaje środków chemicznych w różnych stężeniach. Przeprowadzono badania wpływu tych środków na podstawowe parametry technologiczne płuczki wiertniczej. Następnie próbki płuczek zmodyfikowanych poprzez dodatek wyselekcjonowanych środków były poddawane oddziaływaniu temperatury wynoszącej $130^{\circ} \mathrm{C}$ przez okres 24 godzin. Po tym czasie próbki chłodzono do temperatury $20^{\circ} \mathrm{C}$, następnie mierzono ich parametry technologiczne i porównywano z wynikami uzyskanymi przed postarzaniem w wysokiej temperaturze, a na podstawie otrzymanych wyników dokonywano oceny skuteczności działania poszczególnych środków. Spośród przebadanych środków, których działanie miało zabezpieczać płuczkę wiertniczą przed niekorzystnym wpływem wysokiej temperatury, najkorzystniejsze działanie wykazał mrówczan potasu w połączeniu ze środkiem poliAMPS.
\end{abstract}

Słowa kluczowe: płuczka wiertnicza, odporność termiczna, wiercenia geotermalne.

ABSTRACT: Drilling deep holes or drilling to provide access to thermal waters places increasingly high demands on the properties of the drilling muds. Due to the very high temperature, it may be difficult to maintain the appropriate rheology of the drilling fluid during drilling, especially when an inflow of highly mineralized brines occurs. High temperatures significantly reduce the effectiveness of most of the polymeric agents currently used in the drilling muds technology, in extreme cases causing complete and irreversible damage to their structure. Polymers with ether bonds, which include starches and cellulose, are the most vulnerable. Based on the literature data, it can be concluded that the disadvantages of these polymers can be effectively compensated by the addition of synthetic polymers, e.g. sulfonated polymers. Another direction in improving the thermal resistance of drilling muds indicated in the literature is the use of carbon nanoparticles: graphene flakes and nanotubes. The article presents an analysis of the possibilities of improving thermal stability of drilling muds by using chemical agents that allow to maintain appropriate rheological and structural parameters and filtration at temperatures up to $130^{\circ} \mathrm{C}$. During the tests, three types of chemicals were added to the polymer-potassium drilling mud at different concentrations. The impact of these modifications on technological parameters of the drilling mud was tested. Then, samples modified by the addition of selected agents were exposed to the temperature of $130^{\circ} \mathrm{C}$ for a period of 24 hours. After this time, the samples were cooled to $20^{\circ} \mathrm{C}$, then their technological parameters were measured and compared with the results obtained before aging at high temperature, and based on the obtained results, the effectiveness of individual agents was assessed. Among the agents tested to protect drilling mud against the adverse effects of high temperature, the most beneficial effect was shown by potassium formate in combination with PoliAMPS.

Key words: drilling mud, thermal stability, geothermal drilling.

Autor do korespondencji: B. Jasiński, e-mail: bartlomiej.jasinski@inig.pl

Artykuł nadesłano do Redakcji: 24.11.2020 r. Zatwierdzono do druku: 24.02.2021 r. 


\section{Wstęp}

Energia geotermalna jest jednym z odnawialnych źródeł energii (OZE), ważnych z punktu widzenia idei rozwoju zrównoważonego oraz realizacji przyjętych przez Polskę międzynarodowych zobowiązań w tym zakresie. Ten rodzaj energii wykorzystywany jest na świecie do produkcji energii elektrycznej przy zastosowaniu systemów binarnych parowych instalacji prądotwórczych lub wspomaganych systemów geotermalnych. Elektrownie geotermalne pracują m.in. w Austrii, Niemczech, Islandii czy Stanach Zjednoczonych. W Polsce zastosowanie energii geotermalnej jest jak dotychczas ograniczone. Istnieje kilka zakładów używających energii geotermalnej do celów ciepłowniczych, ponadto wykorzystuje się ją w celach rekreacyjnych oraz zdrowotnych. Nie ma jednak do tej pory komercyjnych instalacji geotermalnych produkujących energię elektryczną. Może się to jednak zmienić w związku z transformacją gospodarki w kierunku nisko- i zeroemisyjnej, a co za tym idzie - coraz większym zainteresowaniem dużych spółek energetycznych wykorzystaniem odnawialnych źródeł energii, do których zaliczana jest energia geotermalna (Polak et al., 2014; Sowiżdżał, 2016). Przeprowadzone dotychczas badania wskazują, że w polskich warunkach wody termalne występują na głębokościach od ok. $1 \mathrm{~km}$ do $4 \mathrm{~km}$ i mają zróżnicowane temperatury - od około $20^{\circ} \mathrm{C}$ do $80-100^{\circ} \mathrm{C}$. Wyniki tych badań przytacza w swoim artykule Hajto, 2018. Są one odpowiednie do zastosowań w ciepłownictwie, rolnictwie, rekreacji, a niekiedy w balneoterapii. Lokalnie w głębszych strukturach geologicznych stwierdzono wody o wyższych temperaturach (do stu kilkudziesięciu stopni Celsjusza). W niektórych rejonach istnieją także warunki do produkcji energii elektrycznej. Oszacowania zasobów energii geotermalnej w skali regionalnej wskazują, że sumaryczne zasoby dostępnej energii geotermalnej zakumulowane w zbiornikach prowincji Niżu Polskiego, Karpat i zapadliska przedkarpackiego wynoszą około 8,86 × $1022 \mathrm{~J}$ (Jarczewski et al., 2015; Kruszewski i Wittig, 2017; Hajto, 2018; Sala, 2018).

Udostępnianie złóż geotermalnych wiąże się z wysokimi wymogami stawianymi stosowanym płuczkom wiertniczym. Trudności podczas wiercenia wynikają głównie z podwyższonej temperatury i ciśnienia oraz czynników związanych ze składem mineralogicznym przewiercanych warstw oraz dopływających wód. W warunkach podwyższonej temperatury dochodzi do obniżenia wartości parametrów reologicznych i do wzrostu filtracji płuczki wiertniczej. Dzieje się tak na skutek zmian fizycznych zachodzących w płuczce pod wpływem temperatury lub w wyniku degradacji polimerów odpowiedzialnych za uzyskanie przez płuczkę odpowiednich parametrów reologicznych i ograniczanie filtracji. W pierwszym przypadku jest to proces odwracalny, natomiast w przypadku degradacji polimeru konieczna jest ciągła obróbka płuczki przez dodatek kolejnych porcji polimeru. Z degradacją polimeru mamy do czynienia szczególnie w przypadku równoczesnego występowania podwyższonej temperatury i skażeń jonami dwuwartościowymi $\left(\mathrm{Ca}^{2+} \mathrm{i} \mathrm{Mg}^{2+}\right)$ (Zima, 2015).

Jednym ze sposobów polepszenia odporności termicznej płuczek wiertniczych jest zastosowanie w ich składzie środków zabezpieczających polimery strukturotwórcze przed degradującym oddziaływaniem wysokiej temperatury. Testy laboratoryjne oraz praktyczne wykonane przez zachodnie firmy płuczkowe (Schlumberger Oilfield Glossary) oraz badania prowadzone w INiG - PIB (Uliasz, 1999) wykazują, że pozytywny wpływ na polepszenie stabilności płuczki wiertniczej w niekorzystnych warunkach wysokiej temperatury i dużego zasolenia mają polimery zsyntetyzowane na bazie monomeru kwasu 2-akryloamido-2-metylopropanosulfonowego (AMPS). Udowodnione zostało, że AMPS wykazuje dużą odporność na zanieczyszczenia elektrolitami, ponadto może stabilizować lepkość, równocześnie obniżając filtrację.

Kolejną grupą środków, które znalazły zastosowanie w technologii płuczkowej, są sole organiczne z grupy mrówczanów. Zaliczają się do nich mrówczan sodu, mrówczan potasu oraz mrówczan cezu. Środki te charakteryzują się właściwościami fizykochemicznymi kwalifikującymi je do stosowania w uciążliwych warunkach otworowych w procesie wiercenia otworów oraz zabiegach udostępniania złóż i rekonstrukcji odwiertów. W technologii cieczy wiertniczych podstawowe znaczenie ma ich dobra rozpuszczalność w wodzie, dzięki czemu można otrzymywać ciężkie roztwory alkaliczne o gęstościach nieosiągalnych dla niektórych soli nieorganicznych oraz kompatybilność z wodami złożowymi i koloidami ochronnymi powszechnie stosowanymi w składach cieczy, głównie ze względu na podwyższanie ich odporności termicznej, a także spełnianie standardów ochrony środowiska (Uliasz et al., 2016).

Do środków coraz częściej stosowanych w wiertnictwie zaliczyć można również nanocząsteczki, w tym nanocząsteczki węgla, jak nanorurki i grafen. Nanotechnologia od dawna znajduje zastosowanie w wielu dziedzinach, a w niektórych, takich jak biologia, informatyka, ochrona środowiska czy energetyka, odgrywa wręcz kluczową rolę (Dębińska, 2015). W ostatnich latach nanomateriały coraz większą popularność zdobywają również w technologii wiertniczej. Wśród wykorzystywanych obecnie płuczek wiertniczych stosuje się tzw. inteligentne systemy płuczkowe. Są to ciecze nano, w których zawarte są cząstki o rozmiarze nanometrów. W zależności od liczby dodatków nanowymiarowych można dokonać podziału płuczek na proste ciecze nano oraz zaawansowane ciecze nano. Płuczki mające w swoim składzie jeden rodzaj nanocząstek nazywane są prostymi nanopłuczkami, natomiast płuczki zawierające więcej niż jeden rodzaj nanocząstek definiowane są jako zaawansowane nanopłuczki. Literatura wskazuje, że 
głównymi zaletami płuczek zawierających nanomateriały są: zmniejszenie uszkodzenia złoża, korzystny wpływ na zapewnienie płynnej pracy w czasie wiercenia, skuteczność w obniżaniu filtracji płuczek wiertniczych, podwyższenie odporności termicznej, skuteczność przy likwidowaniu zaników płuczki (Abdo i Haneef, 2012, 2013; Zima, 2017; Rafati et al., 2018).

\section{Charakterystyka materiałów zastosowanych do badań}

Do badań nad poprawą odporności termicznej płuczek wiertniczych wytypowano następujące środki:

- mrówczan potasu - jedną z najważniejszych cech soli mrówczanowych, z powodzeniem wykorzystywaną w technologii cieczy wiertniczych, jest ich duża rozpuszczalność w wodzie. Solanki mrówczanowe powstające $\mathrm{w}$ wyniku rozpuszczenia soli w wodzie charakteryzują się dużą gęstością. Najmniejszą rozpuszczalność posiada mrówczan sodu, który po rozpuszczeniu w wodzie tworzy solankę o najmniejszej gęstości. Z kolei największą rozpuszczalnością cechuje się mrówczan cezu, tworzący po rozpuszczeniu solankę o największej gęstości. Pomimo wysokiej gęstości roztworów tych soli posiadają one niskie wartości lepkości, które w temperaturze otoczenia wynoszą od około $3 \mathrm{mPa} \cdot \mathrm{s}$ do $14 \mathrm{mPa} \cdot \mathrm{s}$. Najwyższą lepkością charakteryzuje się solanka mrówczanu potasu, ze względu na największą molową koncentrację jonów mrówczanowych. Ponadto solanki te, o wartościach $\mathrm{pH}$ wynoszących od około 8,5 do około 10, tworzą środowisko, w którym zjawiska korozji wykazują znikomy wpływ na osprzęt wiertniczy, są biodegradowalne oraz oddziałują na strukturę cząsteczek otaczającej wody, upodabniając ją bardziej do lodu, co korzystnie wpływa na konformację rozpuszczonych makrocząsteczek polimeru, czyniąc je bardziej uporządkowanymi, sztywnymi i stabilnymi w wysokich temperaturach (Howard, 1995; Uliasz i Herman, 2008; Downs, 2011; Uliasz et al., 2016; Davarpanah i Mirshekari, 2019);

- nanorurki węglowe - jedna $\mathrm{z}$ odmian alotropowych węgla, swoją budową przypominają one walec. Można wyróżnić nanorurki jednowarstwowe, wielowarstwowe, nanocewki, nanotorusy, fuleryty. Nanorurki węglowe odznaczają się doskonałymi właściwościami mechanicznymi, a także elektrycznymi. Wykazują bardzo dużą wartość modułu Younga, rzędu 1012 Pa, dzięki czemu ich deformacje są sprężyste, a nanorurki charakteryzują się dobrą wytrzymałością przy rozciąganiu oraz zginaniu. Ich dobre właściwości wynikają głównie $\mathrm{z}$ występowania silnych wiązań pomiędzy atomami węgla, które znajdują się w płaszczyźnie grafitowej. Ponadto cechują się one dużą powierzchnią właściwą, która w przypadku nanorurek wielościennych osiąga wartości w przedziale $10-20 \mathrm{~m}^{2} / \mathrm{g}$, natomiast jednościennych - aż 100-200 m²/g. Materiały te odznaczają się około 100-krotnie większą wytrzymałością na rozciąganie niż stal. Nanorurki charakteryzują się również bardzo dobrą odpornością na działanie podwyższonej temperatury, sięgającej nawet $2800^{\circ} \mathrm{C}$, oraz są bardzo dobrymi przewodnikami ciepła (Iijima, 2002; Szadkowski i Pingot, 2016; Sahu et al., 2017). Do badań laboratoryjnych użyto nanorurek wielowarstwowych o średnicy zewnętrznej 10-20 nm, średnicy wewnętrznej 5-10 nm oraz długości 10-30 $\mu \mathrm{m}$;

- tlenek grafenu - utleniona forma grafenu, wytworzona w procesie oksydacji kryształów grafitu z mieszanką kwasu siarkowego, azotanu sodu i nadmanganianu potasu (metodą Hummersa). Pod względem budowy molekularnej tlenek grafenu przypomina plaster miodu $\mathrm{z}$ dodatkowymi grupami zawierającymi tlen. Ze względu na wysokie powinowactwo do cząstek wody przez te grupy - tlenek grafenu jest hydrofilowy i można go rozpuścić w wodzie (Nebol'sin et al., 2020; Megantech). Do badań laboratoryjnych użyto roztworu płatków tlenku grafenu o stężeniu 6,2 g/1;

- poli(kwas 2-akryloamido-2-metylopropanosulfonowy) - poliAMPS - organiczny polimer, dobrze rozpuszczalny w wodzie, powstały wskutek polimeryzacji monomeru AMPS. Badania wykazują, że polimery zawierające w składzie monomer AMPS wykazują wysoką odporność na jony wapnia i magnezu (nawet do 75000 ppm). Polimery te najczęściej charakteryzują się dużą masą cząsteczkową, w związku z czym mogą wywoływać zwiększenie lepkości płuczek (Uliasz, 1999). Do badań użyto roztworu o stężeniu 15\%.

\section{Plan badań}

Pierwszym etapem badań było opracowanie składu bazowej płuczki wiertniczej. Musiała się ona charakteryzować odpowiednio niską filtracją oraz optymalnymi wartościami parametrów reologicznych. Pierwszy przetestowany skład (płuczka 1) cechował się bardzo wysoką filtracją $-21,0 \mathrm{~cm}^{3}$ oraz lepkością plastyczną na poziomie $23 \mathrm{mPa} \cdot \mathrm{s}$, lepkością pozorną równą $35 \mathrm{mPa} \cdot \mathrm{s}$ i granicą płynięcia wynoszącą $11,5 \mathrm{~Pa}$. Ograniczenie filtracji polegało na zwiększeniu koncentracji środka skrobiowego - Rotomagu. Przy stężeniu skrobi równym 2,0\% (skład 3) wartość filtracji obniżyła się do $15,2 \mathrm{~cm}^{3}$, jednocześnie do $29 \mathrm{mPa} \cdot \mathrm{s}$ podwyższyła się wartość lepkości plastycznej. Dalsza obróbka płuczki za pomocą Rotomagu powodowała konsekwentne obniżanie filtracji przy jednoczesnym wzroście wartości parametrów reologicznych. Przy stężeniu środka skrobiowego wynoszącym $3,0 \%$ oraz po zastosowaniu blokatora weglanowego w koncentracji 5,0\% (skład6) filtracja miała wartość $9,8 \mathrm{~cm}^{3}$, odnotowano przy tym podwyższenie lepkości plastycznej, lepkości pozornej i granicy płynięcia do poziomu 
Tabela 1. Skład i parametry bazowej płuczki polimerowo-potasowej

Table 1. Composition and parameters of the base polymer-potassium mud

\begin{tabular}{|c|c|c|c|c|c|c|c|c|c|}
\hline \multirow[t]{2}{*}{ Lp. } & \multirow{2}{*}{\multicolumn{2}{|c|}{ Skład płuczki }} & \multirow{2}{*}{$\begin{array}{l}\text { Gęstość } \\
{\left[\mathrm{g} / \mathrm{cm}^{3}\right]}\end{array}$} & \multicolumn{2}{|c|}{$\begin{array}{l}\text { Lepkość } \\
{[\mathrm{mPa} \cdot \mathrm{s}]}\end{array}$} & \multirow{2}{*}{$\begin{array}{c}\begin{array}{c}\text { Granica } \\
\text { płynięcia } \\
\text { [Pa] }\end{array} \\
\tau_{y}\end{array}$} & \multirow{2}{*}{$\begin{array}{c}\text { Wytrzymałość } \\
\text { strukturalna } \\
\text { I/II } \\
{[\mathrm{Pa}]}\end{array}$} & \multirow{2}{*}{$\begin{array}{c}\text { Filtracja } \\
\text { API } \\
{\left[\mathrm{cm}^{3}\right]}\end{array}$} & \multirow[t]{2}{*}{ pH } \\
\hline & & & & $\eta_{p l}$ & $\eta_{s}$ & & & & \\
\hline 1 & $\begin{array}{l}\text { Biostat } \\
\text { XCD } \\
\text { Polofix LV } \\
\text { PAC R } \\
\text { Rotomag } \\
\text { Stabpol S }\end{array}$ & $\begin{array}{c}0,1 \% \\
0,15 \% \\
0,75 \% \\
0,15 \% \\
1,0 \% \\
0,3 \%\end{array}$ & \multirow{5}{*}{1,01} & 23 & 35,0 & 11,5 & $1,5 / 2,0$ & 21,0 & 9,7 \\
\hline 2 & $\begin{array}{l}\text { Biostat } \\
\text { XCD } \\
\text { Polofix LV } \\
\text { PAC R } \\
\text { Rotomag } \\
\text { Stabpol S }\end{array}$ & $\begin{array}{c}0,1 \% \\
0,15 \% \\
0,75 \% \\
0,15 \% \\
1,5 \% \\
0,3 \%\end{array}$ & & 25 & 38,0 & 12,4 & $1,6 / 2,1$ & 17,6 & 9,7 \\
\hline 3 & $\begin{array}{l}\text { Biostat } \\
\text { XCD } \\
\text { Polofix LV } \\
\text { PAC R } \\
\text { Rotomag } \\
\text { Stabpol S }\end{array}$ & $\begin{array}{c}0,1 \% \\
0,15 \% \\
0,75 \% \\
0,15 \% \\
2,0 \% \\
0,3 \% \\
\end{array}$ & & 29 & 44,0 & 14,4 & $1,8 / 2,4$ & 15,2 & 9,7 \\
\hline 4 & $\begin{array}{l}\text { Biostat } \\
\text { XCD } \\
\text { Polofix LV } \\
\text { PAC R } \\
\text { Rotomag } \\
\text { Stabpol S }\end{array}$ & $\begin{array}{c}0,1 \% \\
0,15 \% \\
0,75 \% \\
0,15 \% \\
2,5 \% \\
0,3 \%\end{array}$ & & 32 & 49,5 & 16,8 & $2,1 / 2,8$ & 13,8 & 9,7 \\
\hline 5 & $\begin{array}{l}\text { Biostat } \\
\text { XCD } \\
\text { Polofix LV } \\
\text { PAC R } \\
\text { Rotomag } \\
\text { Stabpol S }\end{array}$ & $\begin{array}{c}0,1 \% \\
0,15 \% \\
0,75 \% \\
0,15 \% \\
3,0 \% \\
0,3 \%\end{array}$ & & 38 & 58,5 & 19,6 & $2,6 / 3,1$ & 12,2 & 9,7 \\
\hline 6 & $\begin{array}{l}\text { Biostat } \\
\text { XCD } \\
\text { Polofix LV } \\
\text { PAC R } \\
\text { Rotomag } \\
\text { Stabpol S } \\
\text { KCl } \\
\text { Blokator M25 }\end{array}$ & $\begin{array}{c}0,1 \% \\
0,15 \% \\
0,75 \% \\
0,15 \% \\
3,0 \% \\
0,3 \% \\
5,0 \% \\
5,0 \%\end{array}$ & 1,06 & 38 & 59,5 & 20,6 & $2,7 / 3,4$ & 9,8 & 9,6 \\
\hline
\end{tabular}

odpowiednio $38 \mathrm{mPa} \cdot \mathrm{s}, 59,5 \mathrm{mPa} \cdot \mathrm{s}$ oraz 20,6 Pa. Dokładne dane przedstawiono w tabeli 1 oraz zobrazowano na rysunku 1.

Następnym krokiem było przeprowadzenie badań wpływu wyselekcjonowanych środków dodawanych do płuczki w różnych stężeniach na jej podstawowe parametry. Dalej próbki płuczki zmodyfikowanej przez dodatek środków były poddawane oddziaływaniu temperatury wynoszącej $130^{\circ} \mathrm{C}$ przez okres 24 godzin. Po tym czasie próbki chłodzono do temperatury $20^{\circ} \mathrm{C}$, następnie mierzono ich parametry technologiczne i porównywano z wynikami uzyskanymi przed postarzaniem w wysokiej temperaturze, a na podstawie otrzymanych wyników dokonywano oceny skuteczności działania poszczególnych środków.

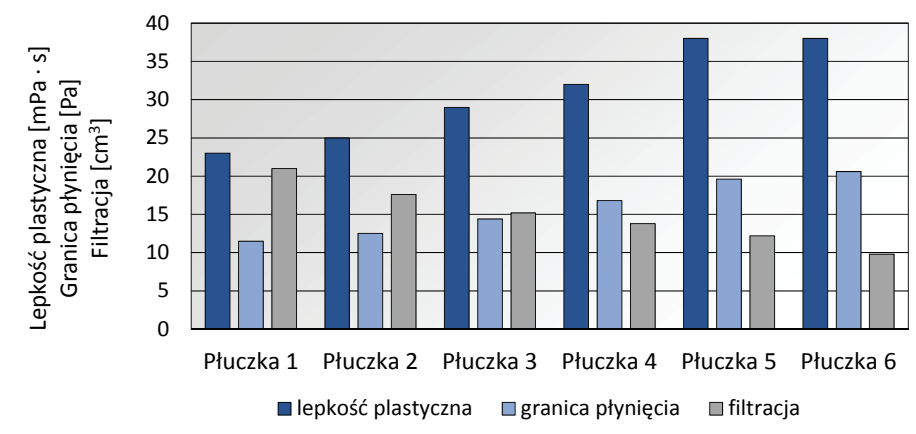

Rys. 1. Zależność parametrów reologicznych i filtracji płuczki od zawartości środka skrobiowego

Fig. 1. Rheological parameters and filtration of the mud depending on the content of starch agent 
Badania zostały przeprowadzone zgodnie z Polską Normą PN-EN ISO 10414-1 i PN-EN ISO 10416. Badania, których nie obejmują wyżej wymienione normy, zostały zrealizowane zgodnie z opracowaną i przyjętą przez pracowników INiG - PIB metodyką badawczą uwzględniającą instrukcje obsługi aparatów oraz specyfikę badań dostosowaną do warunków semiotworopodobnych panujących podczas wiercenia otworów.

\section{Omówienie uzyskanych wyników}

\section{Poli(kwas 2-akryloamido-2-metylopropanosulfonowy) - poliAMPS}

W pierwszej kolejności badano wpływ środka poliAMPS na parametry płuczki wyjściowej. Okazało się, że kwasowy odczyn środka poliAMPS powodował obniżanie $\mathrm{pH}$ płuczki, a co za tym idzie - wzrost wartości filtracji. Z tego powodu postanowiono podwyższyć odczyn pH przy użyciu wodorotlenku potasu do wartości 10-11.

$\mathrm{W}$ tabeli 2 przedstawiono parametry płuczki bazowej oraz próbek, do których dodano poliAMPS w stężeniu 0,5\%, 1,0\% oraz 2,0\%. Można zauważyć, że właściwości reologiczne ulegały podwyższeniu pod wpływem oddziaływania środka, mianowicie lepkość plastyczna przy koncentracji środka wynoszącej 2,0\% miała wartość $45 \mathrm{mPa} \cdot \mathrm{s}$, natomiast granica płynięcia wynosiła w tej samej płuczce 21,5 Pa. Zauważono również, że wraz ze wzrostem stężenia poliAMPS wzrastało $\mathrm{pH}$ płuczek oraz zmniejszała się wartość filtracji, która wyniosła $8,6 \mathrm{~cm}^{3}$ przy 2,0-procentowym stężeniu środka $\left(9,8 \mathrm{~cm}^{3} \mathrm{w}\right.$ płuczce bazowej). Po starzeniu w temperaturze $130^{\circ} \mathrm{C}$ lepkość plastyczna i granica płynięcia płuczki z dodatkiem $0,5 \%$ środka miały wartość odpowiednio $31 \mathrm{mPa} \cdot \mathrm{s}$ i 12,0 Pa. Wartości tych parametrów przy 2,0-procentowym stężeniu środka poliAMPS wynosiły odpowiednio $36 \mathrm{mPa} \cdot \mathrm{s}$ i 13,9 Pa. Podwyższeniu uległa również wielkość filtracji - $10,6 \mathrm{~cm}^{3}$ przy koncentracji środka równej 2,0\%.

Na rysunkach 2 i 3 zaprezentowano zmianę właściwości reologicznych płuczek po starzeniu w temperaturze $130^{\circ} \mathrm{C}$. Spośród płuczek, w których obecny był badany środek, wartości tych parametrów uległy największemu obniżeniu w przypadku stężenia 0,5\% - lepkość plastyczna o $24,4 \%$, a granica płynięcia o 41,7\%. Z kolei najbardziej korzystne działanie miał poliAMPS w przypadku koncentracji w płuczce wynoszącej 2,0\%.

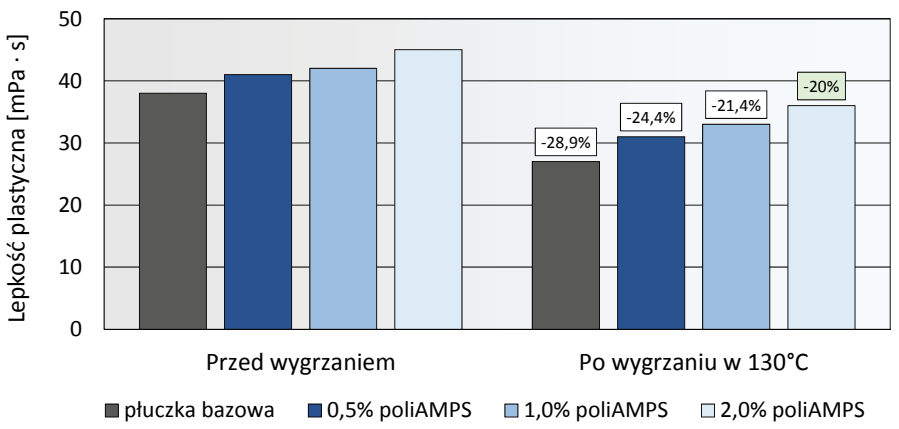

Rys. 2. Porównanie wartości lepkości plastycznej płuczek z dodatkiem poliAMPS

Fig. 2. Plastic viscosity of muds modified with PoliAMPS

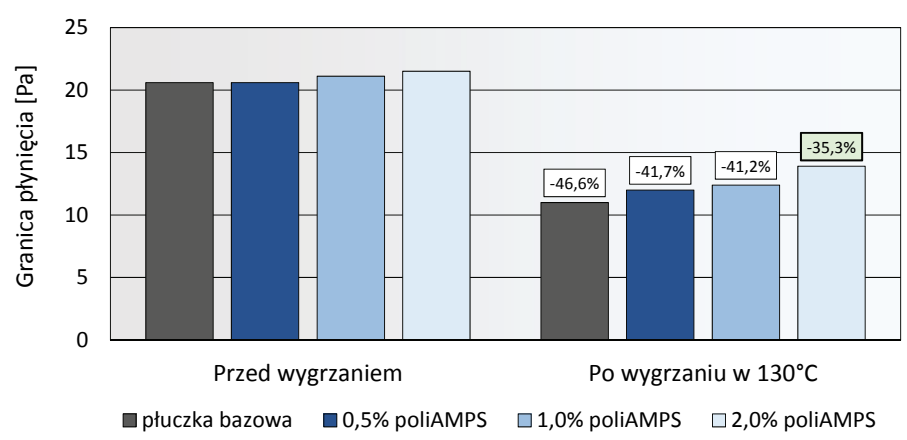

Rys. 3. Porównanie wartości granicy płynięcia płuczek z dodatkiem poliAMPS

Fig. 3. Yield point of muds modified with PoliAMPS

Tabela 2. Właściwości płuczki zmodyfikowanej za pomocą poliAMPS przed i po wygrzaniu w temperaturze $130^{\circ} \mathrm{C}$ przez okres 24 godzin Table 2. Properties of the mud modified with PoliAMPS before and after aging at $130^{\circ} \mathrm{C}$ for 24 hours

\begin{tabular}{|c|c|c|c|c|c|c|c|c|c|}
\hline \multirow[t]{2}{*}{ Lp. } & \multirow{2}{*}{\multicolumn{2}{|c|}{ Skład płuczki }} & \multirow{2}{*}{$\begin{array}{l}\text { Gęstość } \\
{\left[\mathrm{g} / \mathrm{cm}^{3}\right]}\end{array}$} & \multicolumn{2}{|c|}{$\begin{array}{l}\text { Lepkość } \\
{[\mathrm{mPa} \cdot \mathrm{s}]}\end{array}$} & \multirow{2}{*}{$\begin{array}{c}\text { Granica } \\
\text { płynięcia } \\
\text { [Pa] }\end{array}$} & \multirow{2}{*}{$\begin{array}{c}\text { Wytrzymałość } \\
\text { strukturalna } \\
\text { I/II } \\
\text { [Pa] }\end{array}$} & \multirow{2}{*}{$\begin{array}{c}\text { Filtracja } \\
\text { API } \\
{\left[\mathrm{cm}^{3}\right]}\end{array}$} & \multirow[t]{2}{*}{ pH } \\
\hline & & & & $\eta_{p l}$ & $\eta_{s}$ & & & & \\
\hline \multirow{2}{*}{1} & \multirow{2}{*}{ Płuczka bazowa } & & \multirow{8}{*}{1,06} & 38 & 59,5 & 20,6 & $2,7 / 3,4$ & 9,8 & 9,6 \\
\hline & & & & 27 & 38,5 & 11,0 & $1,2 / 1,8$ & 12,2 & 8,9 \\
\hline \multirow{2}{*}{2} & \multirow{2}{*}{$\begin{array}{l}\text { Płuczka bazowa } \\
+ \text { poliAMPS }\end{array}$} & \multirow{2}{*}{$0,5 \%$} & & 41 & 62,5 & 20,6 & $2,7 / 3,5$ & 9,4 & 9,7 \\
\hline & & & & 31 & 43,5 & 12,0 & $1,6 / 2,7$ & 11,6 & 9,0 \\
\hline \multirow{2}{*}{3} & \multirow{2}{*}{$\begin{array}{l}\text { Płuczka bazowa } \\
+ \text { poliAMPS }\end{array}$} & \multirow{2}{*}{$1,0 \%$} & & 42 & 64,0 & 21,1 & $2,9 / 4,0$ & 9,0 & 9,9 \\
\hline & & & & 33 & 46,0 & 12,4 & $1,7 / 2,9$ & 11,4 & 9,1 \\
\hline \multirow{2}{*}{4} & \multirow{2}{*}{$\begin{array}{l}\text { Płuczka bazowa } \\
+ \text { poliAMPS }\end{array}$} & \multirow{2}{*}{$2,0 \%$} & & 45 & 67,5 & 21,5 & $3,2 / 4,2$ & 8,6 & 10,2 \\
\hline & & & & 36 & 50,5 & 13,9 & $1,8 / 3,0$ & 10,6 & 9,2 \\
\hline
\end{tabular}


Tabela 3. Właściwości płuczki zmodyfikowanej za pomocą węglowych nanorurek oraz poliAMPS przed i po wygrzaniu w temperaturze $130^{\circ} \mathrm{C}$ przez okres 24 godzin

Table 3. Properties of the mud modified with carbon nanotubes and PoliAMPS before and after aging at $130^{\circ} \mathrm{C}$ for 24 hours

\begin{tabular}{|c|c|c|c|c|c|c|c|c|c|}
\hline \multirow[t]{2}{*}{ Lp. } & \multirow{2}{*}{\multicolumn{2}{|c|}{ Skład płuczki }} & \multirow{2}{*}{$\begin{array}{l}\text { Gęstość } \\
{\left[\mathrm{g} / \mathrm{cm}^{3}\right]}\end{array}$} & \multicolumn{2}{|c|}{$\begin{array}{l}\text { Lepkość } \\
{[\mathrm{mPa} \cdot \mathrm{s}]}\end{array}$} & \multirow{2}{*}{$\begin{array}{c}\text { Granica } \\
\text { płynięcia } \\
\text { [Pa] }\end{array}$} & \multirow{2}{*}{$\begin{array}{c}\text { Wytrzymałość } \\
\text { strukturalna } \\
\text { I/II } \\
\text { [Pa] }\end{array}$} & \multirow{2}{*}{$\begin{array}{c}\text { Filtracja } \\
\text { API } \\
{\left[\mathrm{cm}^{3}\right]}\end{array}$} & \multirow[t]{2}{*}{ pH } \\
\hline & & & & $\boldsymbol{\eta}_{p l}$ & $\eta_{s}$ & & & & \\
\hline \multirow{2}{*}{1} & \multirow{2}{*}{ Płuczka bazowa } & & 1,06 & 38 & 59,5 & 20,6 & $2,7 / 3,4$ & 9,8 & 9,6 \\
\hline & & & 1,06 & 27 & 38,5 & 11,0 & $1,2 / 1,8$ & 12,2 & 8,9 \\
\hline \multirow{2}{*}{2} & \multirow{2}{*}{$\begin{array}{l}\text { Płuczka bazowa } \\
+ \text { nanorurki }\end{array}$} & \multirow{2}{*}{$0,25 \%$} & 1,06 & 39 & 60,0 & 20,1 & $2,6 / 3,1$ & 9,4 & 9,4 \\
\hline & & & 1,06 & 30 & 42,0 & 11,5 & $1,6 / 2,0$ & 11,4 & 9,0 \\
\hline \multirow{2}{*}{3} & \multirow{2}{*}{$\begin{array}{l}\text { Płuczka bazowa } \\
+ \text { nanorurki }\end{array}$} & \multirow{2}{*}{$0,5 \%$} & 1,06 & 43 & 65,5 & 21,5 & $2,8 / 3,4$ & 9,0 & 9,4 \\
\hline & & & 1,06 & 32 & 45,0 & 12,4 & $1,5 / 2,1$ & 11,0 & 8,9 \\
\hline \multirow{2}{*}{4} & \multirow{2}{*}{$\begin{array}{l}\text { Płuczka bazowa } \\
+ \text { nanorurki }\end{array}$} & \multirow{2}{*}{$1,0 \%$} & 1,06 & 44 & 67,0 & 22,0 & $2,8 / 3,5$ & 8,0 & 9,3 \\
\hline & & & 1,06 & 33 & 46,5 & 12,9 & $1,8 / 2,4$ & 10,6 & 8,9 \\
\hline \multirow{2}{*}{5} & \multirow{2}{*}{$\begin{array}{l}\text { Płuczka bazowa } \\
+ \text { nanorurki } \\
+ \text { poliAMPS }\end{array}$} & \multirow{2}{*}{$\begin{array}{c}0,25 \% \\
0,5 \%\end{array}$} & 1,06 & 42 & 63,0 & 20,1 & $2,8 / 3,4$ & 8,8 & 9,5 \\
\hline & & & 1,06 & 33 & 45,0 & 11,5 & $1,4 / 1,8$ & 9,8 & 9,1 \\
\hline \multirow{2}{*}{6} & \multirow{2}{*}{$\begin{array}{l}\text { Płuczka bazowa } \\
+ \text { nanorurki } \\
+ \text { poliAMPS }\end{array}$} & \multirow{2}{*}{$\begin{array}{c}0,25 \% \\
1,0 \%\end{array}$} & 1,06 & 42 & 65,0 & 22,0 & $3,0 / 3,7$ & 8,0 & 9,5 \\
\hline & & & 1,06 & 32 & 45,5 & 12,9 & $1,6 / 2,3$ & 8,2 & 9,0 \\
\hline \multirow{2}{*}{7} & \multirow{2}{*}{$\begin{array}{l}\text { Płuczka bazowa } \\
+ \text { nanorurki } \\
+ \text { poliAMPS }\end{array}$} & \multirow{2}{*}{$\begin{array}{l}0,5 \% \\
0,5 \%\end{array}$} & 1,06 & 43 & 65,5 & 21,5 & $2,9 / 3,5$ & 8,0 & 9,5 \\
\hline & & & 1,06 & 34 & 47,0 & 12,4 & $1,7 / 2,3$ & 7,8 & 9,0 \\
\hline \multirow{2}{*}{8} & \multirow{2}{*}{$\begin{array}{l}\text { Płuczka bazowa } \\
+ \text { nanorurki } \\
+ \text { poliAMPS }\end{array}$} & \multirow{2}{*}{$\begin{array}{l}0,5 \% \\
1,0 \%\end{array}$} & 1,06 & 46 & 69,0 & 22,0 & $3,2 / 3,6$ & 7,2 & 9,6 \\
\hline & & & 1,06 & 36 & 50,0 & 13,4 & $1,7 / 2,4$ & 6,8 & 9,0 \\
\hline \multirow{2}{*}{9} & \multirow{2}{*}{$\begin{array}{l}\text { Płuczka bazowa } \\
+ \text { nanorurki } \\
+ \text { poliAMPS }\end{array}$} & $1,0 \%$ & 1,06 & 44 & 67,5 & 22,5 & $3,0 / 3,7$ & 7,6 & 9,5 \\
\hline & & $0,5 \%$ & 1,06 & 36 & 50,0 & 13,4 & $2,1 / 2,7$ & 6,5 & 8,9 \\
\hline 10 & Płuczka bazowa & $1,0 \%$ & 1,06 & 47 & 71,0 & 23,0 & $3,3 / 3,8$ & 5,8 & 9,6 \\
\hline 10 & + poliAMPS & $1,0 \%$ & 1,06 & 39 & 54,0 & 14,4 & $1,9 / 2,8$ & 6,0 & 9,0 \\
\hline
\end{tabular}

\section{Nanorurki weglowe}

Kolejnym środkiem badanym pod kątem polepszenia odporności termicznej płuczek wiertniczych były wielościenne nanorurki węglowe. Aby wprowadzić je do płuczki, uprzednio sporządzano zawiesiny odpowiedniej ilości nanorurek w $50 \mathrm{~cm}^{3}$ wody, używając $\mathrm{w}$ tym celu sonifikatora przez okres 5 minut. Ilości środków tworzących płuczkę bazową były tak dobrane, aby osiągnąc zakładaną koncentrację po wprowadzeniu poszczególnych zawiesin. Przetestowano wpływ samych nanorurek, jak również w połączeniu z poliAMPS.

$\mathrm{W}$ tabeli 3 przedstawione zostały parametry płuczki bazowej oraz płuczek $\mathrm{z}$ dodatkiem nanorurek w stężeniu $0,25 \%, 0,5 \%$ oraz $1,0 \%$ oraz poliAMPS w stężeniu $0,5 \%$ i $1,0 \%$. Parametry reologiczne płuczki były coraz wyższe wraz ze wzrostem koncentracji nanorurek węglowych. Przy stężeniu 0,25\% lepkość plastyczna i granica płynięcia miały wartości wynoszące odpowiednio $39 \mathrm{mPa} \cdot \mathrm{s}$ oraz $20,1 \mathrm{~Pa}$, podczas gdy przy koncentracji nanorurek równej 2,0\% wynosiły one $44 \mathrm{mPa} \cdot \mathrm{s}$ oraz 22,0 Pa. Dodatek nanorurek miał pozytywny wpływ na filtrację. W przypadku zastosowania dwóch środków zauważyć można podwyższenie wartości parametrów reologicznych płuczek w stosunku do płuczek, w których składzie były tylko nanorurki. Mianowicie w przypadku stężenia nanorurek $1,0 \%$ oraz poliAMPS $1,0 \%$ lepkość plastyczna miała wartość $47 \mathrm{mPa} \cdot \mathrm{s}$, a granica płynięcia 23,0 Pa. Odnotowano również zmniejszenie się filtracji.

Po 24-godzinnym wygrzewaniu w temperaturze $130^{\circ} \mathrm{C}$ najwyższe wartości parametrów reologicznych spośród próbek zawierających jeden środek miała płuczka $\mathrm{z}$ dodatkiem 1,0\% nanorurek, w tym przypadku lepkość plastyczna wynosiła $33 \mathrm{mPa} \cdot \mathrm{s}$, a granica płynięcia 12,9 Pa. Przy koncentracji środka wynoszącej 0,25\% filtracja płuczki miała wartość $11,4 \mathrm{~cm}^{3}$, natomiast w płuczce z 1,0-procentowym dodatkiem nanorurek było to $10,6 \mathrm{~cm}^{3}$. Z kolei spośród próbek zawierających dwa środki najwyższymi wartościami parametrów reologicznych 
odznaczała się płuczka zawierająca po 1,0\% nanorurek i poliAMPS. Lepkość plastyczna i granica płynięcia wynosiły odpowiednio $39 \mathrm{mPa} \cdot \mathrm{s}$ i 14,4 Pa. Również w przypadku tego składu zanotowano najniższą filtrację wynoszącą $6,0 \mathrm{~cm}^{3}$.

Na rysunkach 4 oraz 5 przedstawione zostały zmiany wartości parametrów reologicznych płuczek z dodatkiem nanorurek po starzeniu $\mathrm{w}$ temperaturze $130^{\circ} \mathrm{C} \mathrm{w}$ porównaniu do parametrów płuczek przed wygrzewaniem. Zmiany wartości lepkości plastycznej były bardzo podobne przy wszystkich stężeniach nanorurek, a najlepszy rezultat otrzymano przy koncentracji $0,25 \%$ i było to $23,1 \%$. W przypadku granicy płynięcia najmniejsza różnica wystąpiła w płuczce $\mathrm{z}$ dodatkiem 1,0\% nanorurek i wynosiła 41,4\%.

Na rysunkach 6 oraz 7 przedstawione zostały zmiany wartości parametrów reologicznych płuczek z dodatkiem nanorurek i poliAMPS po starzeniu w temperaturze $130^{\circ} \mathrm{C} \mathrm{w}$ porównaniu do parametrów płuczek przed wygrzewaniem. Najlepszy rezultat otrzymano przy koncentracji każdego ze środków

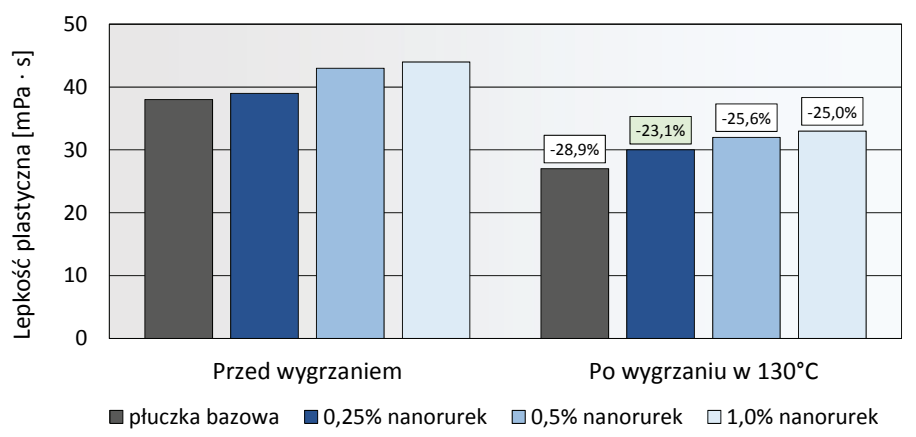

Rys. 4. Porównanie wartości lepkości plastycznej płuczek z dodatkiem nanorurek węglowych

Fig. 4. Plastic viscosity of muds modified with carbon nanotubes wynoszącej $1,0 \%$ i było to $17,0 \%$. Również w przypadku granicy płynięcia zdecydowanie najkorzystniejszy wynik uzyskano w tym składzie płuczki - 37,4\%.

\section{Tlenek grafenu - GO}

Roztwór tlenku grafenu zastosowany do badań miał stężenie 6,2 g/l. Wprowadzano go do płuczki bazowej w ten sposób, aby zawartość czystego tlenku grafenu w płuczkach wynosiła $0,1 \%, 0,2 \%$ oraz $0,5 \%$. Okazało się, że tak dodany do płuczki bazowej środek wykazywał niewielką zdolność do dyspergowania, co skutkowało tworzeniem się niejednorodnej cieczy. W związku z tym postanowiono, że w pierwszej kolejności sporządzane będą z użyciem sonifikatora zawiesiny tlenku grafenu, a dopiero do tak przygotowanych cieczy dodawana będzie reszta środków tworzących płuczkę. Oprócz płuczek obrobionych jedynie tlenkiem grafenu badano również wpływ jednoczesnego zastosowania GO i poliAMPS. Do każdej płuczki zawierającej kolejno $0,1 \%, 0,2 \%$ oraz $0,5 \%$ GO dodawano poliAMPS

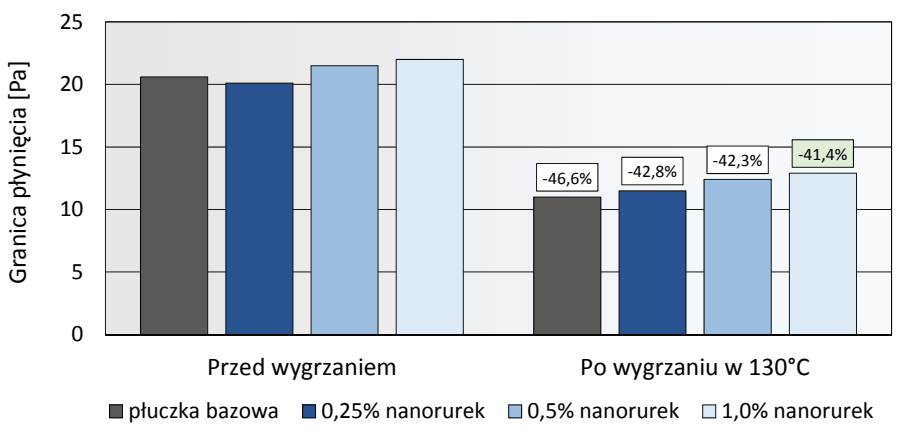

Rys. 5. Porównanie wartości granicy płynięcia płuczek z dodatkiem nanorurek węglowych

Fig. 5. Yield point of muds modified with carbon nanotubes
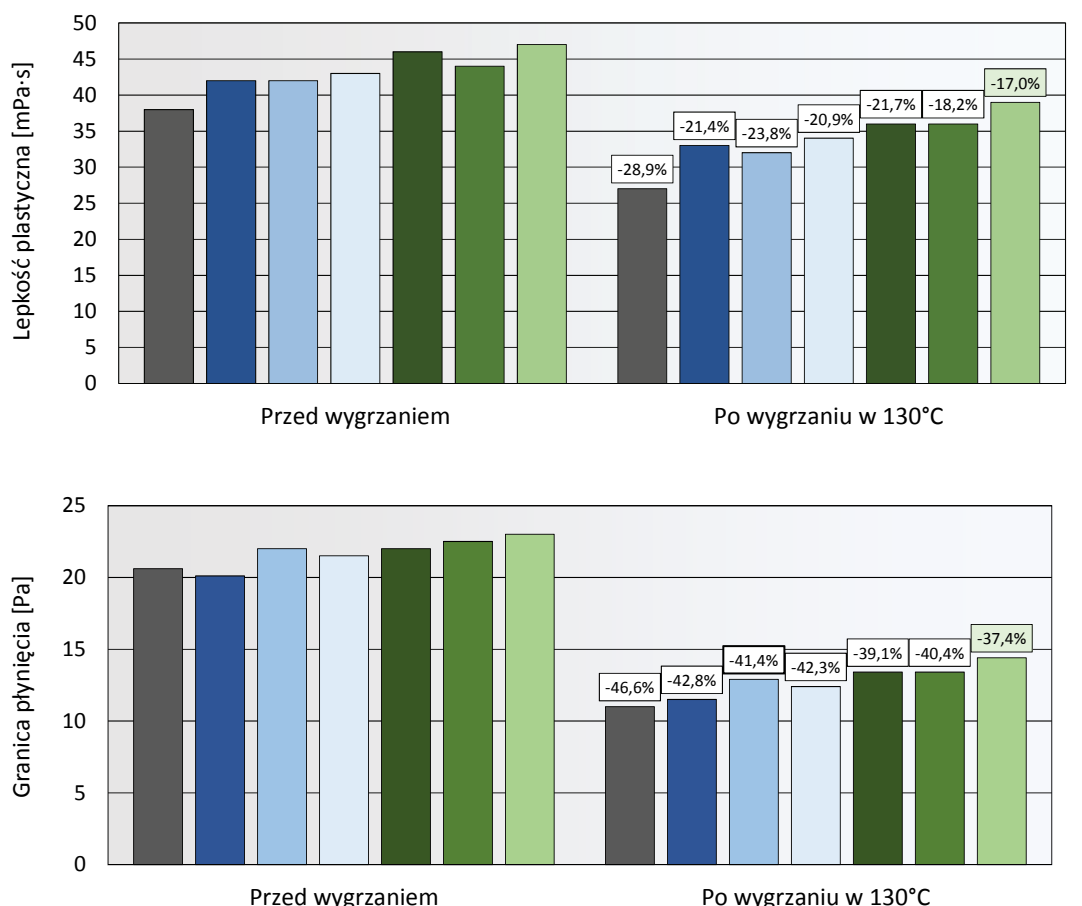

- płuczka bazowa

$0,25 \%$ nanorurek $0,5 \%$ poliAMPS $\square 0,25 \%$ nanorurek $1,0 \%$ poliAMPS $\square 0,5 \%$ nanorurek $0,5 \%$ poliAMPS 0,5\% nanorurek $1,0 \%$ poliAMPS $1,0 \%$ nanorure $0,5 \%$ poliAMPS $\square 1,0 \%$ nanorure $1,0 \%$ poliAMPS

upłuczka bazowa

$\square 0,25 \%$ nanorurek $0,5 \%$ poliAMPS $\square 0,25 \%$ nanorurek $1,0 \%$ poliAMPS $\square 0,5 \%$ nanorurek $0,5 \%$ poliAMPS $0,5 \%$ nanorure $1,0 \%$ poliAMPS $1,0 \%$ nanorurek $0,5 \%$ poliAMPS $\square 1,0 \%$ nanorurek $1,0 \%$ poliAMPS
Rys. 6. Porównanie wartości lepkości plastycznej płuczek z dodatkiem węglowych nanorurek oraz poliAMPS

Fig. 6. Plastic viscosity of muds modified with carbon nanotubes and PoliAMPS

Rys. 7. Porównanie wartości granicy płynięcia płuczek z dodatkiem węglowych nanorurek oraz poliAMPS

Fig. 7. Yield point of muds modified with carbon nanotubes and PoliAMPS 
Tabela 4. Właściwości płuczki zmodyfikowanej za pomocą tlenku grafenu oraz poliAMPS przed i po wygrzaniu w temperaturze $130^{\circ} \mathrm{C}$ przez okres 24 godzin

Table 4. Properties of the mud modified with graphene oxide and PoliAMPS before and after aging at $130^{\circ} \mathrm{C}$ for 24 hours

\begin{tabular}{|c|c|c|c|c|c|c|c|c|c|}
\hline \multirow[t]{2}{*}{ Lp. } & \multicolumn{2}{|c|}{ Skład płuczki } & \multirow{2}{*}{$\begin{array}{l}\text { Gęstość } \\
{\left[\mathrm{g} / \mathrm{cm}^{3}\right]}\end{array}$} & \multicolumn{2}{|c|}{$\begin{array}{l}\text { Lepkość } \\
{[\mathrm{mPa} \cdot \mathrm{s}]}\end{array}$} & \multirow{2}{*}{$\begin{array}{c}\text { Granica } \\
\text { płynięcia } \\
\text { [Pa] }\end{array}$} & \multirow{2}{*}{$\begin{array}{c}\text { Wytrzymałość } \\
\text { strukturalna } \\
\text { I/II } \\
\text { [Pa] }\end{array}$} & \multirow{2}{*}{$\begin{array}{c}\text { Filtracja } \\
\text { API } \\
{\left[\mathrm{cm}^{3}\right]}\end{array}$} & \multirow[t]{2}{*}{ pH } \\
\hline & & & & $\eta_{p l}$ & $\boldsymbol{\eta}_{s}$ & & & & \\
\hline \multirow{2}{*}{1} & \multirow{2}{*}{$\begin{array}{l}\text { Płuczka bazowa } \\
+ \text { tlenek grafenu }\end{array}$} & \multirow{2}{*}{$0,1 \%$} & 1,06 & 40 & 61,5 & 20,6 & $2,9 / 3,6$ & 10,8 & 9,2 \\
\hline & & & 1,06 & 29 & 41,5 & 12,0 & $1,5 / 2,1$ & 14,6 & 8,6 \\
\hline \multirow{2}{*}{2} & \multirow{2}{*}{$\begin{array}{l}\text { Płuczka } 1 \\
+ \text { poliAMPS }\end{array}$} & \multirow{2}{*}{$0,5 \%$} & 1,06 & 40 & 62,0 & 21,1 & $3,0 / 3,6$ & 9,8 & 9,3 \\
\hline & & & 1,06 & 31 & 41,5 & 10,1 & $1,5 / 2,5$ & 13,2 & 8,8 \\
\hline \multirow{2}{*}{3} & \multirow{2}{*}{$\begin{array}{l}\text { Płuczka } 1 \\
+ \text { poliAMPS }\end{array}$} & \multirow{2}{*}{$1,0 \%$} & 1,06 & 41 & 65,0 & 22,0 & $3,1 / 3,7$ & 9,4 & 9,4 \\
\hline & & & 1,06 & 32 & 46,0 & 13,4 & $1,9 / 2,8$ & 12,6 & 8,9 \\
\hline \multirow{2}{*}{4} & \multirow{2}{*}{$\begin{array}{l}\text { Płuczka bazowa } \\
+ \text { tlenek grafenu }\end{array}$} & \multirow{2}{*}{$0,2 \%$} & 1,06 & 46 & 68,0 & 21,1 & $3,3 / 3,8$ & 9,6 & 9,2 \\
\hline & & & 1,06 & 34 & 46,5 & 12,0 & $1,9 / 2,9$ & 11,2 & 8,6 \\
\hline \multirow{2}{*}{5} & \multirow{2}{*}{$\begin{array}{l}\text { Płuczka } 4 \\
+ \text { poliAMPS }\end{array}$} & \multirow{2}{*}{$0,5 \%$} & 1,06 & 45 & 68,0 & 22,0 & $3,3 / 3,8$ & 7,0 & 9,3 \\
\hline & & & 1,06 & 35 & 48,5 & 12,9 & $2,0 / 2,9$ & 11,2 & 8,8 \\
\hline \multirow{2}{*}{6} & \multirow{2}{*}{$\begin{array}{l}\text { Płuczka } 4 \\
+ \text { poliAMPS }\end{array}$} & \multirow{2}{*}{$1,0 \%$} & 1,06 & 46 & 69,5 & 22,5 & $3,4 / 4,1$ & 6,6 & 9,4 \\
\hline & & & 1,06 & 36 & 50,5 & 13,9 & $2,2 / 3,1$ & 10,2 & 8,9 \\
\hline \multirow{2}{*}{7} & \multirow{2}{*}{$\begin{array}{l}\text { Płuczka bazowa } \\
+ \text { tlenek grafenu }\end{array}$} & \multirow{2}{*}{$0,5 \%$} & 1,06 & 46 & 69,5 & 22,5 & $3,4 / 4,1$ & 6,8 & 9,1 \\
\hline & & & 1,06 & 35 & 48,5 & 12,9 & $2,0 / 3,0$ & 10,8 & 8,5 \\
\hline \multirow{2}{*}{8} & \multirow{2}{*}{$\begin{array}{l}\text { Płuczka } 7 \\
+ \text { poliAMPS }\end{array}$} & \multirow{2}{*}{$0,5 \%$} & 1,06 & 46 & 70,5 & 23,5 & $3,5 / 4,0$ & 6,8 & 9,3 \\
\hline & & & 1,06 & 36 & 50,5 & 13,9 & $2,1 / 3,0$ & 10,0 & 8,8 \\
\hline \multirow{2}{*}{9} & \multirow{2}{*}{$\begin{array}{l}\text { Płuczka } 7 \\
+ \text { poliAMPS }\end{array}$} & $10 \%$ & 1,06 & 47 & 74,0 & 25,9 & $3,8 / 4,7$ & 6,2 & 9,4 \\
\hline & & $1,0 \%$ & 1,06 & 39 & 56,0 & 16,3 & $2,3 / 3,4$ & 9,8 & 8,9 \\
\hline
\end{tabular}

w ilości 0,5\% oraz 1,0\%. Wyniki badań właściwości tak przygotowanych składów zaprezentowano w tabeli 4. Płuczka z dodatkiem $0,1 \%$ tlenku grafenu charakteryzowała się lepkością plastyczną o wartości $40 \mathrm{mPa} \cdot \mathrm{s}$ oraz granicą płynięcia równą 20,6 Pa. Wartości te uległy podwyższeniu do odpowiednio $46 \mathrm{mPa} \cdot \mathrm{s}$ i 21,1 Pa przy stężeniu GO wynoszącym $0,2 \%$ oraz do $46 \mathrm{mPa} \cdot$ s i 22,5 Pa przy stężeniu 0,5\%. Dodatkowe wprowadzenie do składu płuczki poliAMPS skutkowało dalszym wzrostem tych parametrów, w płuczce zawierającej 0,5\% tlenku grafenu oraz 1,0\% poliAMPS lepkość plastyczna i granica płynięcia

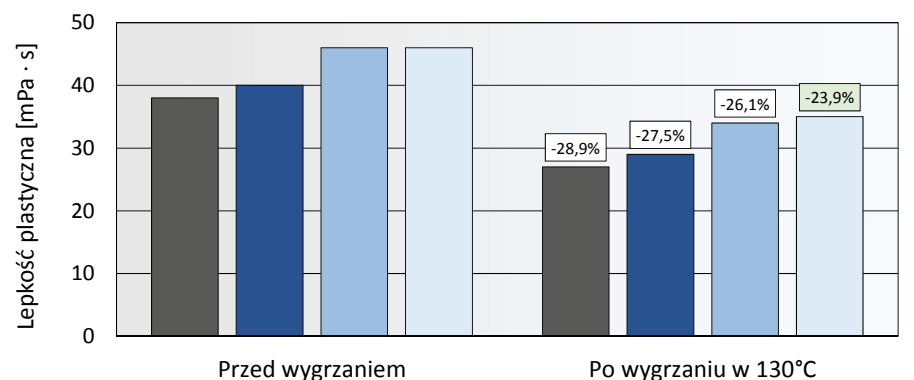

$\square$ płuczka bazowa $\square 0,1 \%$ tlenku grafenu $\square 0,2 \%$ tlenku grafenu $\square 0,5 \%$ tlenku grafenu

Rys. 8. Porównanie wartości lepkości plastycznej płuczek z dodatkiem tlenku grafenu

Fig. 8. Plastic viscosity of muds modified with graphene oxide miały wartości odpowiednio $47 \mathrm{mPa} \cdot \mathrm{s}$ i 25,9 Pa. Zauważyć można również pozytywny wpływ tych środków na filtrację płuczek.

Po oddziaływaniu na próbki temperatury $130^{\circ} \mathrm{C}$ płuczka zawierająca $0,5 \%$ tlenku grafenu oraz $1,0 \%$ poliAMPS odznaczała się najwyższymi wartościami parametrów reologicznych, lepkość plastyczna i granica płynięcia wynosiły odpowiednio $39 \mathrm{mPa} \cdot \mathrm{s}$ i 16,3 Pa. Również w przypadku tego składu zanotowano najniższą filtrację wynoszącą $9,8 \mathrm{~cm}^{3}$. Porównanie parametrów reologicznych płuczek zawierających tlenek grafenu przed i po starzeniu przedstawiono na rysunkach 8 i 9.

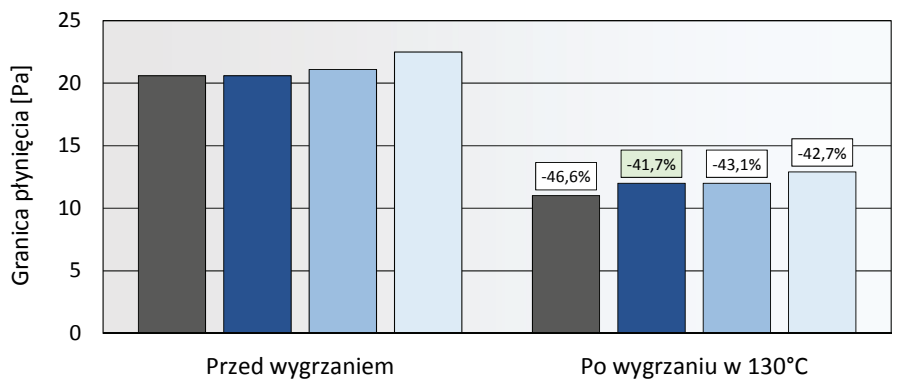

口płuczka bazowa $\square 0,1 \%$ tlenku grafenu $\square 0,2 \%$ tlenku grafenu $\square 0,5 \%$ tlenku grafenu

Rys. 9. Porównanie wartości granicy płynięcia płuczek z dodatkiem tlenku grafenu

Fig. 9. Yield point of muds modified with graphene oxide 

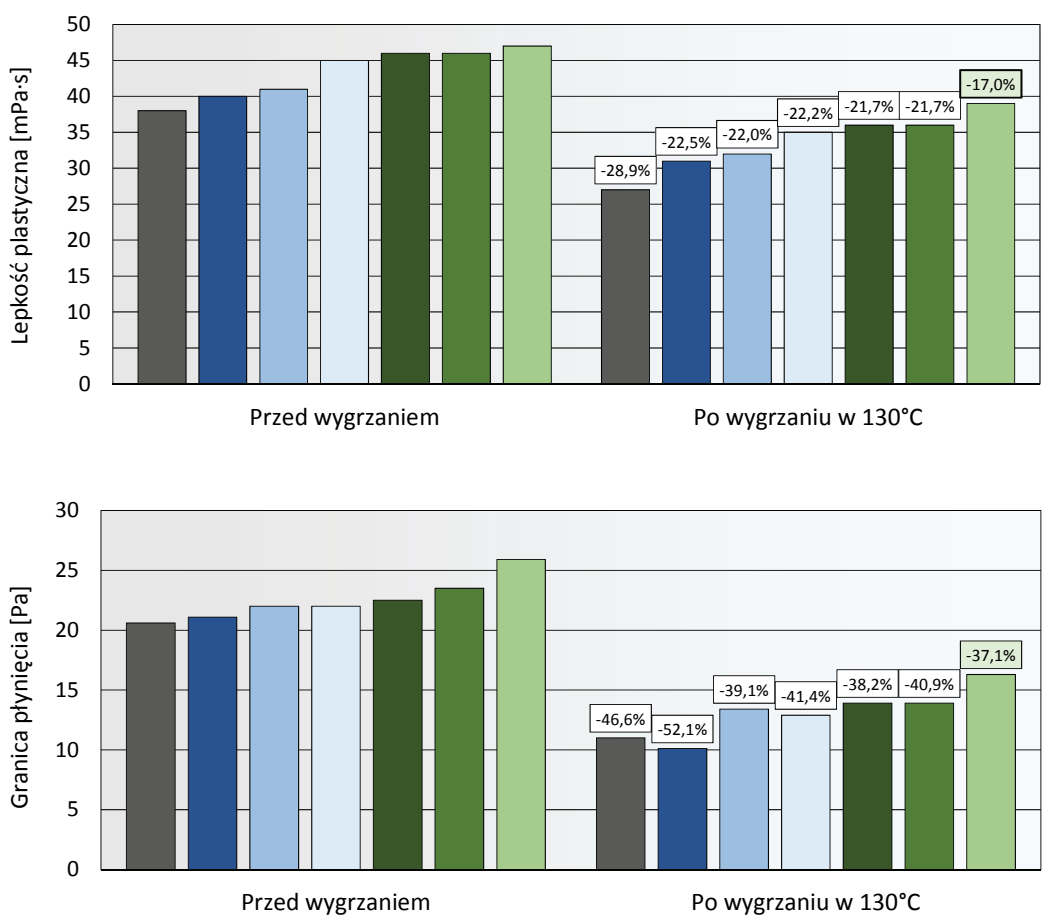

płuczka bazowa

- $0,1 \%$ tlenku grafenu $0,5 \%$ poliAMPS $0,1 \%$ tlenku grafenu 1,0\% PpoliAMPS $\square 0,2 \%$ tlenku grafenu $0,5 \%$ poliAMPS 0,2\% tlenku grafenu $1,0 \%$ poliAMPS

$\square 0,5 \%$ tlenku grafenu $0,5 \%$ poliAMPS $0,5 \%$ tlenku grafenu $1,0 \%$ poliAMPS
Rys . 10. Porównanie wartości lepkości plastycznej płuczek $\mathrm{z}$ dodatkiem tlenku grafenu oraz poliAMPS

Fig. 10. Plastic viscosity of muds modified with graphene oxide and PoliAMPS płuczka bazowa

$\square, 1 \%$ tlenku grafenu $0,5 \%$ poliAMPS $\square, 1 \%$ tlenku grafenu $1,0 \%$ poliAMPS $\square, 2 \%$ tlenku grafenu $0,5 \%$ poliAMPS $\square, 2 \%$ tlenku grafenu $1,0 \%$ poliAMPS $0,5 \%$ tlenku grafenu $0,5 \%$ poliAMPS $\square 0,5 \%$ tlenku grafenu $1,0 \%$ poliAMPS
Rys. 11. Porównanie wartości granicy płynięcia płuczek z dodatkiem tlenku grafenu oraz poliAMPS

Fig. 11. Yield point of muds modified with graphene oxide and PoliAMPS
Na rysunkach 10 i 11 zaprezentowano wartości właściwości reologicznych płuczek z dodatkiem tlenku grafenu oraz poliAMPS przed wygrzaniem oraz po wygrzaniu w temperaturze $130^{\circ} \mathrm{C}$. Najmniej efektywna okazała się kombinacja $0,1 \%$ GO i $0,5 \%$ poliAMPS - w tym przypadku odnotowano największą różnicę zarówno lepkości plastycznej, jak i granicy płynięcia. Z kolei najbardziej efektywnym działaniem wykazało się połączenie $0,5 \%$ tlenku grafenu i 1,0\% poliAMPS, w przypadku którego wartość lepkości plastycznej uległa obniżeniu o $17,0 \%$, a granicy płynięcia o $37,1 \%$.

\section{Mrówczan potasu}

Ostatnim z przetestowanych środków był mrówczan potasu. Wprowadzano go do płuczki w postaci solanki nasyconej o gęstości $1,56 \mathrm{~g} / \mathrm{cm}^{3}$. Sporządzono pięć składów płuczek, w których solanka stanowiła kolejno 25,0\%, 37,5\%,
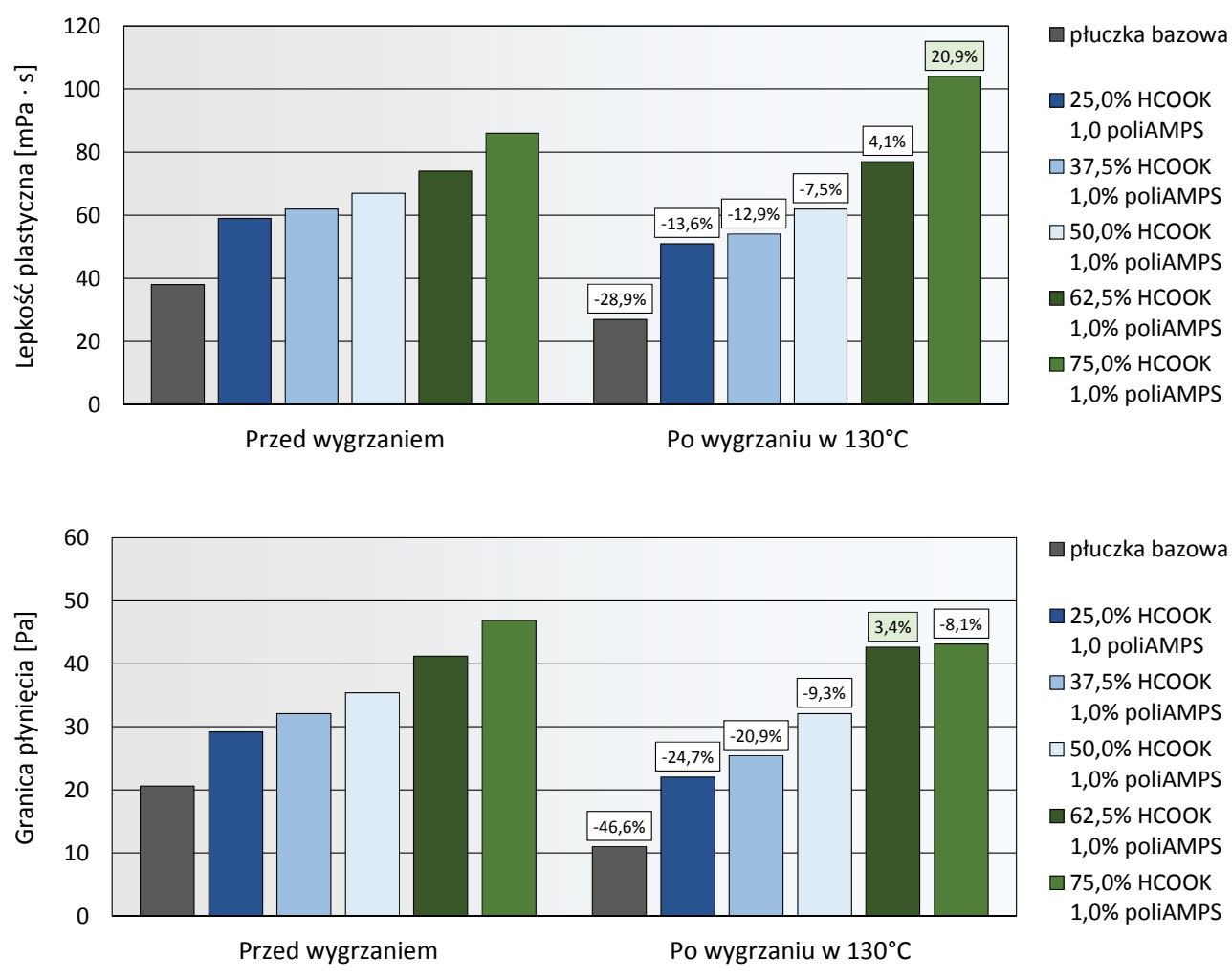

Rys. 12. Porównanie wartości lepkości plastycznej płuczek na osnowie roztworu mrówczanu potasu z dodatkiem poliAMPS

Fig. 12. Plastic viscosity of muds modified with potassium formate brine and PoliAMPS
Rys. 13. Porównanie wartości granicy płynięcia płuczek na osnowie roztworu mrówczanu potasu z dodatkiem poliAMPS

Fig. 13. Yield point of muds modified potassium formate brine and PoliAMPS 
$50 \%, 62,5 \%$ oraz $75,0 \%$. Dodatkowo każdy ze składów zawierał poliAMPS w ilości 1,0\%. Wyniki pomiarów parametrów tak przygotowanych składów zestawiono w tabeli 5. Można zauważyć, że wyjściowe parametry reologiczne płuczek zawierających solankę sporządzoną na bazie mrówczanu potasu są znacznie wyższe niż w przypadku płuczki bazowej i ulegają podwyższeniu wraz ze wzrostem stężenia solanki. Płuczka zawierająca 25,0\% solanki charakteryzuje się lepkością plastyczną o wartości $59 \mathrm{mPa} \cdot \mathrm{s}$ oraz granicą płynięcia o wartości 29,2 Pa. W płuczce zawierającej 50,0\% solanki wartości te wynosiły już $67 \mathrm{mPa} \cdot \mathrm{s}$ oraz $35,4 \mathrm{~Pa}$, natomiast w płuczce o zawartości solanki wynoszącej 75,0\%

Tabela 5. Właściwości płuczki na osnowie roztworu mrówczanu potasu oraz modyfikowanej poliAMPS przed i po wygrzaniu w temperaturze $130^{\circ} \mathrm{C}$ przez okres 24 godzin

Table 5. Properties of the mud modified with potassium formate brine and PoliAMPS before and after aging at $130^{\circ} \mathrm{C}$ for 24 hours

\begin{tabular}{|c|c|c|c|c|c|c|c|c|c|}
\hline \multirow[t]{2}{*}{ Lp. } & \multicolumn{2}{|c|}{ Skład płuczki } & \multirow{2}{*}{$\begin{array}{l}\text { Gęstość } \\
{\left[\mathrm{g} / \mathrm{cm}^{3}\right]}\end{array}$} & \multicolumn{2}{|c|}{$\begin{array}{l}\text { Lepkość } \\
{[\mathrm{mPa} \cdot \mathrm{s}]}\end{array}$} & \multirow{2}{*}{$\begin{array}{c}\text { Granica } \\
\text { płynięcia } \\
\text { [Pa] }\end{array}$} & \multirow{2}{*}{$\begin{array}{c}\text { Wytrzymałość } \\
\text { strukturalna } \\
\text { I/II } \\
{[\mathrm{Pa}]}\end{array}$} & \multirow{2}{*}{$\begin{array}{c}\text { Filtracja } \\
\text { API } \\
{\left[\mathrm{cm}^{3}\right]}\end{array}$} & \multirow[t]{2}{*}{ pH } \\
\hline & & & & $\eta_{p l}$ & $\eta_{s}$ & & & & \\
\hline \multirow{2}{*}{1} & \multirow{2}{*}{$\begin{array}{l}\text { Solanka HCOOK } \\
\text { Biostat } \\
\text { XCD } \\
\text { Polofix LV } \\
\text { PAC R } \\
\text { Rotomag } \\
\text { Stabpol S } \\
\text { Blokator M25 } \\
+ \text { poliAMPS }\end{array}$} & \multirow{2}{*}{$\begin{array}{c}25,0 \% \\
0,1 \% \\
0,15 \% \\
0,75 \% \\
0,15 \% \\
3,0 \% \\
0,3 \% \\
5,0 \% \\
1,0 \% \\
\end{array}$} & 1,18 & 59 & 89,5 & 29,2 & $3,2 / 3,9$ & 7,8 & 9,7 \\
\hline & & & 1,18 & 51 & 74 & 22,0 & $2,7 / 4,2$ & 8,8 & 9,2 \\
\hline \multirow[b]{2}{*}{2} & \multirow{2}{*}{$\begin{array}{l}\text { Solanka HCOOK } \\
\text { Biostat } \\
\text { XCD } \\
\text { Polofix LV } \\
\text { PAC R } \\
\text { Rotomag } \\
\text { Stabpol S } \\
\text { Blokator M25 } \\
\text { + poliAMPS } \\
\end{array}$} & \multirow{2}{*}{$\begin{array}{c}37,5 \% \\
0,1 \% \\
0,15 \% \\
0,75 \% \\
0,15 \% \\
3,0 \% \\
0,3 \% \\
5,0 \% \\
1,0 \% \\
\end{array}$} & 1,26 & 62 & 95,5 & 32,1 & $3,4 / 4,4$ & 7,0 & 9,9 \\
\hline & & & 1,26 & 54 & 80,5 & 25,4 & $3,0 / 3,7$ & 8,6 & 9,6 \\
\hline \multirow[b]{2}{*}{3} & \multirow{2}{*}{$\begin{array}{l}\text { Solanka HCOOK } \\
\text { Biostat } \\
\text { XCD } \\
\text { Polofix LV } \\
\text { PAC R } \\
\text { Rotomag } \\
\text { Stabpol S } \\
\text { Blokator M25 } \\
\text { + poliAMPS }\end{array}$} & \multirow{2}{*}{$\begin{array}{c}50,0 \% \\
0,1 \% \\
0,15 \% \\
0,75 \% \\
0,15 \% \\
3,0 \% \\
0,3 \% \\
5,0 \% \\
1,0 \%\end{array}$} & 1,32 & 67 & 104 & 35,4 & $4,4 / 6,0$ & 5,8 & 10,3 \\
\hline & & & 1,32 & 62 & 95,5 & 32,1 & $3,5 / 4,4$ & 6,6 & 10,0 \\
\hline \multirow{2}{*}{4} & \multirow{2}{*}{$\begin{array}{l}\text { Solanka HCOOK } \\
\text { Biostat } \\
\text { XCD } \\
\text { Polofix LV } \\
\text { PAC R } \\
\text { Rotomag } \\
\text { Stabpol S } \\
\text { Blokator M25 } \\
\text { + poliAMPS }\end{array}$} & \multirow{2}{*}{$\begin{array}{c}62,5 \% \\
0,1 \% \\
0,15 \% \\
0,75 \% \\
0,15 \% \\
3,0 \% \\
0,3 \% \\
5,0 \% \\
1,0 \%\end{array}$} & 1,37 & 74 & 115,5 & 41,2 & $4,8 / 6,3$ & 5,4 & 10,4 \\
\hline & & & 1,37 & 77 & 121,5 & 42,6 & $5,1 / 6,4$ & 6,2 & 10,2 \\
\hline \multirow[b]{2}{*}{5} & \multirow{2}{*}{$\begin{array}{l}\text { Solanka HCOOK } \\
\text { Biostat } \\
\text { XCD } \\
\text { Polofix LV } \\
\text { PAC R } \\
\text { Rotomag } \\
\text { Stabpol S } \\
\text { Blokator M25 } \\
\text { + poliAMPS }\end{array}$} & \multirow{2}{*}{$\begin{array}{c}75,0 \% \\
0,1 \% \\
0,15 \% \\
0,75 \% \\
0,15 \% \\
3,0 \% \\
0,3 \% \\
5,0 \% \\
1,0 \%\end{array}$} & 1,44 & 86 & 135 & 46,9 & $7,3 / 9,1$ & 3,8 & 10,7 \\
\hline & & & 1,44 & 104 & 149 & 43,1 & $6,6 / 8,20$ & 6,4 & 10,6 \\
\hline
\end{tabular}


było to odpowiednio $86 \mathrm{mPa} \cdot \mathrm{s}$ i 46,9 $\mathrm{Pa}$. Po wygrzaniu próbek lepkość plastyczna i granica płynięcia płuczki zawierającej 25,0\% solanki na bazie mrówczanu potasu miały wartości odpowiednio $51 \mathrm{mPa} \cdot \mathrm{s}$ i 22,0 Pa. W płuczce mającej w składzie $75,0 \%$ solanki wartości te wynosiły odpowiednio $104 \mathrm{mPa} \cdot \mathrm{s}$ i 41,3 $\mathrm{Pa}$.

Na rysunkach 12 i 13 zaprezentowano zmianę właściwości reologicznych płuczek po starzeniu w temperaturze $130^{\circ} \mathrm{C}$. Okazało się, że w wyniku oddziaływania temperatury na płuczki o zawartości solanki $62,5 \%$ oraz 75,0\% nastąpiło zwiększenie wartości parametrów reologicznych. W przypadku płuczki zawierającej 75,0\% solanki różnica wartości lepkości plastycznej przed i po wygrzaniu wynosiła 20,9\%. Takie zachowanie płuczek może wskazywać na zajście w nich zjawiska koagulacji. Polega ono na łączeniu się cząstek układu koloidalnego w większe skupienia, co może skutkować żelowaniem i wzrostem reologii takiego układu. Koagulacja może zostać wywołana między innymi poprzez wprowadzenie do układu elektrolitu, wytworzenie w nim pola elektrycznego bądź podwyższenie temperatury (Raczkowski i Półchłopek, 1998). Zakładając, że w płuczkach o najwyższym stężeniu mrówczanu potasu doszło do koagulacji, najbardziej odporna na działanie temperatury okazała się płuczka o zawartości solanki 50,0\% oraz poliAMPS w stężeniu 1,0\%. Wartości lepkości plastycznej i granicy płynięcia zmniejszyły się odpowiednio o $7,5 \%$ i $9,3 \%$.

\section{Wnioski}

Analiza wyników badań pozwoliła przedstawić następujące wnioski:

1. Spośród przebadanych środków, których użycie miało zabezpieczać płuczkę wiertniczą przed niekorzystnym wpływem wysokiej temperatury, najlepsze działanie wykazuje mrówczan potasu w połączeniu z poliAMPS. Należy jednak zwrócić uwagę, że przy zbyt dużej zawartości w płuczce roztworu nasyconego sporządzonego na mrówczanie potasu dochodziło do znacznego wzrostu wartości parametrów reologicznych po oddziaływaniu na płuczkę wysokiej temperatury. Może to wskazywać na zachodzenie w takich płuczkach niekorzystnego zjawiska koagulacji. Odrzucając płuczki, w których zawartość solanki wynosiła $62,5 \%$ oraz $75,0 \%$, najlepsze wyniki uzyskano dla płuczki zawierającej $50,0 \%$ roztworu nasyconego mrówczanu potasu oraz $1,0 \%$ poliAMPS. Płuczka ta po 24-godzinnym oddziaływaniu temperatury wynoszącej $130^{\circ} \mathrm{C}$ charakteryzowała się wartościami lepkości plastycznej i granicy płynięcia wynoszącymi odpowiednio $62 \mathrm{mPa} \cdot \mathrm{s}$ i 32,1 Pa. Były to wartości niższe niż przed wygrzaniem jedynie o $7,5 \%$ oraz $9,3 \%$.
2. Wpływ pozostałych zastosowanych podczas badań środków na poprawę odporności termicznej płuczek wiertniczych jest wyraźnie niższy niż mrówczanu potasu. Spośród płuczek modyfikowanych przez dodatek środka poliAMPS najniższa różnica między wartościami lepkości plastycznej płuczki wygrzanej w temperaturze $130^{\circ} \mathrm{C}$ i płuczki niewygrzewanej wynosiła 20,0\%, a w przypadku granicy płynięcia 35,3\%. Dla najbardziej odpornej płuczki obrobionej węglowymi nanorurkami i poliAMPS wyniki te wynosiły 17,0\% i 37,4\%, natomiast w przypadku najstabilniejszej termicznie płuczki z dodatkiem tlenku grafenu i poliAMPS było to $17,0 \%$ i $37,1 \%$.

3. Poli(kwas 2-akryloamido-2-metylopropanosulfonowy) charakteryzuje się niskim odczynem $\mathrm{pH}$. Z tego powodu aplikowanie go do płuczek powoduje obniżanie ich odczynu, co z kolei ma negatywny wpływ na filtrację płuczek. $\mathrm{Z}$ tego względu środek przed dodaniem do płuczki zobojętniano przy użyciu wodorotlenku potasu.

4. Wszystkie badane środki wykazują działanie ograniczające filtrację płuczek, przy czym najbardziej korzystne wyniki uzyskano w przypadku płuczek zawierających mrówczan potasu w połączeniu z poliAMPS oraz węglowe nanorurki w połączniu z poliAMPS.

Artykuł powstał na podstawie pracy statutowej pt. Analiza możliwości podwyższenia odporności termicznej płuczek wiertniczych poprzez dobór środków chemicznych - praca INiG - PIB na zlecenie MNiSW; nr zlecenia: 0046/KW/2020, nr archiwalny: DK-4100-0034/2020.

\section{Literatura}

Abdo J., Haneef M.D., 2012. Nano-Enhanced Drilling Fluids: Pioneering Approach to Overcome Uncompromising Drilling Problems. Journal of Energy Resources Technology, 134(1): 014501. DOI: $10.1115 / 1.4005244$.

Abdo J., Haneef M.D., 2013. Clay Nanoparticles Modified Drilling Fluids for Drilling of Deep Hydrocarbon Wells. Applied Clay Science, 86: 76-82. DOI: 10.1016/j.clay.2013.10.017.

Davarpanah A., Mirshekari B., 2019. Effect of formate fluids on the shale stabilization of shale layers. Energy Reports, 5: 987-992. DOI: 10.1016/j.egyr.2019.07.016.

Dębińska E., 2015. Niekonwencjonalne zaczyny cementowe z dodatkiem nanokrzemionki. Nafta-Gaz, 5: 290-300.

Downs J.D., 2011. Life Without Barite: Ten Years of Drilling Deep HPHT Gas Wells With Cesium Formate Brine. Society of Petroleum Engineers. DOI: 10.2118/145562-MS.

Hajto M., 2018. Potencjał geotermalny Polski oraz możliwości adaptacji międzynarodowej klasyfikacji zasobów geotermalnych UNFC2009. Nafta-Gaz, 12: 898-904. DOI: 10.18668/NG.2018.12.04 .

Howard S.K., 1995. Formate Brines for Drilling and Completion: State of the Art. Society of Petroleum Engineers. DOI: 10.2118/30498-MS.

Iijima S., 2002. Carbon nanotubes: past, present, and future. Physica B: Condensed Matter, 323(1-4): 1-5. DOI: 10.1016/ S0921-4526(02)00869-4. 
Jarczewski W., Huculak M., Dej M., 2015. Wykorzystanie energii geotermalnej w Polsce. Prace Geograficzne, 141: 87-104. DOI: 10.4467/20833113PG.15.011.4063.

Kruszewski M., Wittig V., 2017. Wiercenia geotermalne za wodami w stanie nadkrytycznym jako szansa na zrewolucjonizowanie światowego rynku energii. Wiadomości Naftowe i Gazownicze, 12(230): 4-8.

Megantech. <http://www.megantech.pl> (dostęp: 28.10.2020).

Nebol'sin V.A., Galstyan V., Silina Y.E., 2020. Graphene oxide and its chemical nature: Multi-stage interactions between the oxygen and Graphene. Surfaces and Interfaces, 21. DOI: 10.1016/j. surfin.2020.100763.

Polak R., Dziki D., Krzykowski A., Rudy S., Różyło R., 2014. Elektrownie geotermalne oparte na systemach binarnych. Motrol. Motoryzacja i Energetyka Rolnictwa, 16: 101-104.

Raczkowski J., Półchłopek T., 1998. Materiały i środki chemiczne do sporządzania płuczek wiertniczych. Prace Instytutu Górnictwa Naftowego i Gazownictwa, 95: 1-319.

Rafati R., Smith S.R., Haddad A.S., Novara R., Hamidi H., 2018. Effect of nanoparticles on the modifications of drilling fluids properties: A review of recent advances. Journal of Petroleum Science and Engineering, 161: 61-76. DOI:10.1016/j.petrol.2017.11.067.

Sahu A., Jain A., Gulbake A., 2017. The role of carbon nanotubes in nanobiomedicines. International Journal of Pharmacy and Pharmaceutical Sciences, 9(6): 235-251. DOI: 10.22159/ ijpps.2017v9i6.18522.

Sala K., 2018. Przemysłowe wykorzystanie energii geotermalnej w Polsce na przykładzie geotermalnego zakładu ciepłowniczego w Bańskiej Niżnej. Prace Komisji Geografii Przemystu Polskiego Towarzystwa Geograficznego, 32: 73-82.

Schlumberger Oilfield Glossary. <http://www.glossary.oilfield.slb. com> (dostęp: 21.10.2020).

Sowiżdżał A., 2016. Potencjał geotermalny zbiorników mezozoicznych Niżu Polskiego do produkcji energii elektrycznej. Technika Poszukiwań Geologicznych, 55: 105-115.
Szadkowski B., Pingot M., 2016. Nanorurki węglowe - materiał przyszłości. Eliksir, 1: 16-19.

Uliasz M., 1999. Badania laboratoryjne krajowych polimerów sulfonowanych w zastosowaniu do płuczek wiertniczych o pełnym zasoleniu i skażonych jonami dwuwartościowymi. Prace Instytutu Nafty i Gazu, Kraków. Archiwum Instytutu Nafty i Gazu - Państwowego Instytutu Badawczego, Kraków.

Uliasz M., Herman Z., 2008. Wymagane parametry cieczy roboczych dla ochrony pierwotnych właściwości skał zbiornikowych. Wiertnictwo Nafta Gaz, 25: 753-764.

Uliasz M., Zima G., Błaż S., Jasiński B., 2016. Roztwory mrówczanów jako składniki płuczek wiertniczych. Przemyst Chemiczny, 95: 297-302. DOI: 10.15199/62.2016.2.22.

Zima G., 2015. Nowy rodzaj płuczki wiertniczej do zastosowania w warunkach HPHT. Nafta-Gaz, 8: 556-564.

Zima G., 2017. Analiza wpływu nanomateriałów na właściwości osadu filtracyjnego. Nafta-Gaz, 5: 312-320. DOI: 10.18668/ NG.2017.05.03.

\section{Dokumenty normatywne}

Norma PN-EN ISO 10414-1 Przemysł naftowy i gazowniczy. Badania polowe płynów wiertniczych. Część 1: Płyny na bazie wody.

Norma PN-EN ISO 10416 Przemysł naftowy i gazowniczy. Płyny wiertnicze. Badania laboratoryjne.

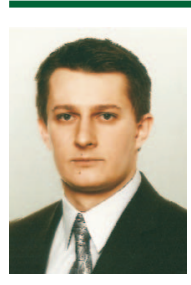

Mgr inż. Bartłomiej JASIŃSKI

Starszy specjalista badawczo-techniczny Zakładzie

Technologii Wiercenia

Instytut Nafty i Gazu - Państwowy Instytut Badawczy ul. Lubicz 25 A

31-503 Kraków

E-mail: bartlomiej.jasinski@inig.pl

\section{OFERTA BADAWCZA ZAKKADU TECHNOLOGII WIERCENIA}

- opracowywanie sktadów i technologii sporządzania wodnodyspersyjnych i olejowodyspersyjnych płuczek wiertniczych, cieczy specjalnych (roboczych, nadpakerowych, buforowych, przemywających) i zaczynów cementowych do wiercenia otworów i rekonstrukcji odwiertów w warunkach normalnej i wysokiej temperatury oraz występowania różnych ciśnień ztożowych i skażeń chemicznych;

- dobór właściwości płuczek wiertniczych, zaczynów cementowych, cieczy buforowych oraz opracowanie metod usuwania osadów filtracyjnych w celu poprawy skuteczności cementowania otworów wiertniczych;

- badania serwisowe ptuczek wiertniczych podczas wiercenia otworu oraz zaczynów cementowych w trakcie zabiegu cementowania;

- specjalistyczne badania laboratoryjne dotyczące oznaczania: wptywu cieczy wiertniczych na przewiercane skaty, napięcia powierzchniowego na granicy faz, wspótczynnika tarcia w warunkach HPHT, sedymentacji materiatu obciążaiącego, wynoszenia zwiercin w otworach kierunkowych i poziomych, doboru materiałów uszczelniających do zapobiegania ucieczkom płuczki wiertniczej i zaczynu cementowego w warstwy szczelinowate, odporności na migrację gazu w wiążącym zaczynie cementowym w warunkach otworopodobnych, odporności korozyjnej kamienia cementowego, związków chemicznych w cieczach wiertniczych i ich toksyczności przy użyciu bakterii jako bioindykatorów;

- zagospodarowywanie zużytych ptuczek wiertniczych i urobku.

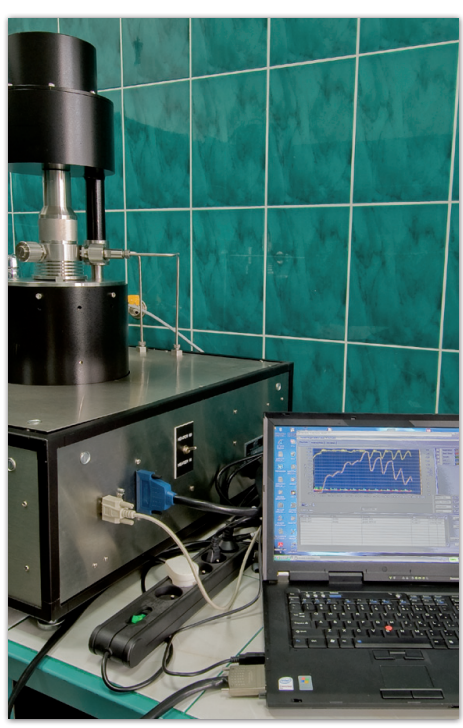

INSTYTUT NAFTY I GAZU - Państwowy Instytut Badawczy 